SINET: Ethiop. J. Sci., 25(2):155-175, 2002

(C) Faculty of Science, Addis Ababa University, 2002

ISSN: 0379-2897

\title{
PLANT COMMUNITY ANALYSIS AND ECOLOGY OF AFROMONTANE AND TRANSITIONAL RAINFOREST VEGETATION OF SOUTHWESTERN ETHIOPIA
}

\author{
Kumelachew Yeshitela ${ }^{1}$ and Tamrat Bekele ${ }^{2, *}$ \\ ${ }^{1}$ Forest Genetic Resources Conservation Project \\ Institute of Biodiversity Conservation and Research, PO Box 30726 \\ Addis Ababa, Ethiopia, E-mail: kumeyesh@hotmail.com \\ ${ }^{2}$ Department of Biology, Faculty of Science, Addis Ababa University \\ PO Box 3434, Addis Ababa, Ethiopia, E-mail: Biology.aau@telecom.net.et
}

\begin{abstract}
The plant communities of the forests of southwestern Ethiopia were described based on floristic analysis of the data collected between February 1995 and May 1996. Floristic analysis is based on the cover-abundance values of both woody and herbaceous species. Plant community-environment relationship was assessed based on topographic and some soil physical and chemical characteristics. A total of 101 relevés were analysed at altitudes between 1050 and $2550 \mathrm{~m}$ a.s.l. (metres above sea level), and a total of 139 species of vascular plants were identified. Nine plant community types were described. Most of these show significant variations for most of the environmental parameters studied. The species in the forest were phytogeographically related to the Afromontane, Guineo-Congolean or Guineo-Congolean linking species.
\end{abstract}

\section{Key words/phrases: Afromontane, classification, Ethiopia, plant commu- nity, transitional rainforest}

\section{INTRODUCTION}

The forest vegetation cover of Ethiopia has been declining continuously. In the early 1950 's, $16 \%$ of the land area of Ethiopia was covered with forests (EFAP, 1994). In the early 1980's, the forest coverage was reported at $3.6 \%$ and in 1989 it was estimated at only $2.7 \%$ (EFAP, 1994). At present, most of the remaining forests of Ethiopia are confined to the south and southwest.

The forests of southwestern Ethiopia are home to various wild animals and contain the gene pool of various endemic and indigenous plants including Coffea arabica L., which accounts for more than three-quarters of the world's coffee production, Aframomum corrorima (Braun) Jansen, Scadoxus nutans (Friis \& Bjørnstad) Friis \& Nordal, and Vepris dainellii (Pich-Serm.) Kokwaro.

\footnotetext{
To whom all coresspondence should be addressed.
} 
The flora and vegetation of southwestern Ethiopia have been the subject of study by Logan (1946), Chaffey (1979), Friis et al. (1982), and Friis (1992). Among these studies, only Friis et al. (1982) utilized floristic analysis for the description of the forest vegetation. However, this description neither attempted to identify the plant communities, nor did it explain the environmental relationships of these communities. In the present study, an attempt has been made to address both aspects. Therefore, the objectives of the present study were: (1) to study the floristic composition of the forest vegetation of southwestern Ethiopia with an aim to identify the plant communities; and (2) to understand the ecological relationships between the plant communities and the environmental parameters.

\section{STUDY AREA}

The forests investigated in this study stretch between 1050 and $2550 \mathrm{~m}$ a.s.l. and include Jiren forest, Yayu forest, Gebre Dima forest, Sele-Anderacha forest, Bonga forest, Sheko forest, and Belete-Gera forest. These forests are located between $6^{\circ} 53^{\prime}$ to $8^{\circ} 27^{\prime} \mathrm{N}$ latitudes and $35^{\circ} 15^{\prime}$ to $36^{\circ} 50^{\prime} \mathrm{E}$ longitudes (see Fig. 1). The forest of Sele-Anderacha at $670 \mathrm{kms}$ distance from Addis Ababa is the furthest while Belete-Gera forest is the closest at $380 \mathrm{kms}$.

The basement of the study area contains Precambrian rocks and Tertiary lavas that lie directly on the crystalline basement. These lava flows were accompanied by, and altered with, the eruption of large amounts of ash and coarser fragmental material forming the trap series (Mohr, 1971).

The soils of the southwest plateau reflect the change of topography and the drop in temperature and increased rainfall associated with higher altitude. Soils developed on the steep lands of escarpments and along ridges are thin and young. Rolling terrain at altitudes between 1200 and $1800 \mathrm{~m}$ a.s.l. favours the formation of deep, reddish, well-drained soils which, despite their favourable physical structure and excellent internal drainage, are only moderately fertile. At higher elevations clay illuviation becomes increasingly important and the soils lose their reddish colour to become light brown or yellowish brown. According to the soil classification system by FAO (1974), the soil order of the study area is Nitosol.

The southwestern region of Ethiopia is the wettest with eight rainy months that extend from March to October. According to Daniel Gamachu (1977), the annual rainfall of the highlands in the southwest ranges between 1400 and $2200 \mathrm{~mm}$. However, the rainfall data from the period 1982-1994 from stations nearby show an average annual rainfall between 1600 and $2552 \mathrm{~mm}$. The mean annual temperatures are between 15 to $25^{\circ} \mathrm{C}$, the mean daily tempera- 
ture minima range from 9.7 to $16.3^{\circ} \mathrm{C}$ and the corresponding maxima from 20 to $30.4^{\circ} \mathrm{C}$.

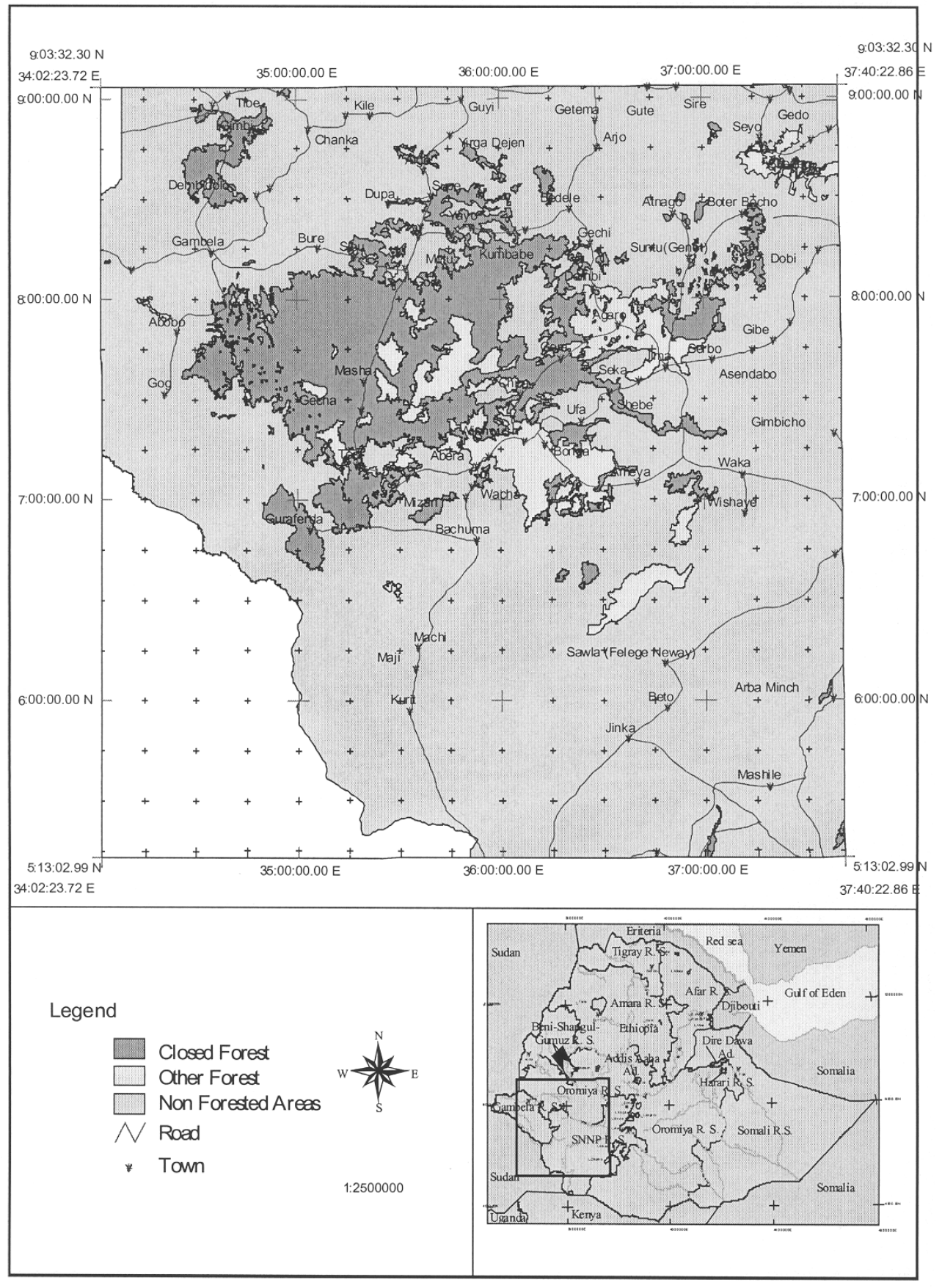

Fig. 1. Study area showing distribution of closed forest. 
The vegetation of the study area consists of forests, bush lands, woodlands, and grasslands (Friis et al., 1982). According to Friis (1992), three forest types are recognized in southwestern Ethiopia: lowland dry peripheral semievergreen Guineo-Congolean forest, Afromontane rainforest, and Transitional Rainforest. Human impact on the vegetation is severe. Many forested areas have been converted into agricultural land. Some of the forests in the study area may be secondary or belong to different serial stages in the regrowth of the forests.

\section{MATERIALS AND METHODS}

\section{Vegetation analysis}

A reconnaissance survey was made across the forests of southwestern Ethiopia in March 1995 in order to obtain an impression of the site conditions and physiognomy of the vegetation, and to identify sampling sites. Vegetation data were collected during February 1995, April 1995, December - January 1996 and May 1996.

During sampling, visually checked homogenous representative stands were selected and sample plots of $900 \mathrm{~m}^{2}(30 \mathrm{~m} \times 30 \mathrm{~m})$ were delimited by relascope and tape. In order to reduce the effect of human interference, the sites selected were, as much as possible, far away from the main road and human settlements. Floristic analysis inside the plot was carried out following the procedure of Braun-Blanquet (see Poore, 1955; 1956; Becking, 1957; MuellerDombois and Ellenberg, 1974; Westhoff and Van der Maarel, 1978). All vascular plant species present in the sampling unit were recorded and the non-epiphytic and non-climbing plants were rated according to their cover/abundance using the modified cover-abundance scale of BraunBlanquet (Van der Maarel, 1979). Floristic analysis of herbaceous species was made on a $2 \mathrm{~m} \times 2 \mathrm{~m}$ subplot laid within the larger plot where the vegetation was assumed to be representative.

Identification of plant species was made at the National Herbarium (ETH), Addis Ababa University. Nomenclature follows Cuffodontis (1953-1972), Hedberg and Edwards (1989; 1995) and Edwards et al. (1995).

\section{Site description, soil sampling and soil analysis}

At each sampling site altitude was measured using "Thommen" altimeter, aspect was measured using "Type 15 SILVA" compass, and slope was measured using a clinometer. Soil samples up to $20 \mathrm{~cm}$ depth (topsoil) and 60 $\mathrm{cm}$ depth (subsoil) were collected from five points in each sample plot, four at the corners and one at the middle. A composite soil sample weighing about $1.5 \mathrm{~kg}$ was taken for further analysis. 
Soil analysis was performed in the soil laboratories of Addis Ababa University and Ministry of Agriculture, Addis Ababa, following the procedures outlined in Jou (1978), Chopra and Kanwar (1982), and Dewis and Frietas (1984). The soil samples were analyzed for texture, using the Bouyoucos hydrometer method, $\mathrm{pH}$ using a glass electrode $\mathrm{pH}$-meter, and electrical conductivity using conductivity-meter. Available phosphorus was determined following Bray No. 1 method, organic matter according to the Walkely-Black method, and total nitrogen following Kjeldahl method. Exchangeable bases and cation exchange capacity were determined by extracting with ammonium acetate, at $\mathrm{pH} 7$ using flame photometer for sodium and potassium and atomic absorption spectrophotometer for calcium and magnesium.

\section{Data analysis}

The cover-abundance values of the species were used as class entities to classify the floristic data using Average-linkage clustering procedure with the program SYNTAX: PROGRAMME NCLAS-Hierarchical clustering by distance optimization (Podani, 1988). In the SYNTAX program, similarity ratio was selected for resemblent coefficient and dissimilarities among the various sample plots were measured using average linkage.

The values of environmental parameters for all sample plots that make up a particular community type were added and averaged for the topsoil and subsoil separately. Aspect was codified according to Zerihun Woldu et al. (1989): $\mathrm{N}=0$; $\mathrm{NE}=1 ; \mathrm{E}=2 ; \mathrm{SE}=3 ; \mathrm{S}=4 ; \mathrm{SW}=3.3, \mathrm{~W}=2.5 ; \mathrm{NW}=1.3$; Ridge top = 4. Analysis of variance (ANOVA) was performed to detect variation among the community types with respect to any one environmental parameter. Duncan's multiple range test was performed to detect significant differences among the different means of the environmental parameters of each community type. Pearson's product moment correlation coefficient was calculated to evaluate the relationship between the environmental parameters. These statistical analyses were performed with the program STATISTICA.

\section{RESULTS AND DISCUSSION}

\section{Floristics}

A total of 139 species of vascular plants representing 56 families were recorded from the tree, shrub, and field layers. Of these $41.7 \%$ were trees, $10.1 \%$ trees/shrubs, $12.9 \%$ shrubs, and $35.2 \%$ herbs. Seventy-one per cent of the families were dicots, $14.6 \%$ monocots, and $14.3 \%$ pteridophytes. Seventyseven per cent of the species were dicots, while $15.1 \%$ monocots, and $7.9 \%$ pteridophytes. The families with the highest number of species were Euphorbiaceae and Moraceae (10 species each) among the dicots, Poaceae (7 species) among monocots, and Aspleniaceae (3 species) among Pteridophytes. Fifteen species of vascular epiphytes belonging to 9 families were recorded. Four species belonged to Orchidaceae, while 3 species belonged to 
Polypodiaceae, and 2 species belonged to Piperaceae. The families Adianthaceae, Amaryllidaceae, Aspleniaceae, Camponviaceae, Lycopodiaceae, and Oleandraceae were represented with one species each. Twelve species of woody climbers (lianas) belonging to 11 families were recorded from the quadrats. Two of the species belonged to the family Celasteraceae/Hippocrateaceae, whereas the rest belonged to Apocynaceae, Araceae, Combretaceae, Menispermaceae, Myrsinaceae, Oleaceae, Phytolaccaceae, Ranunculaceae, Rhamnaceae and Urticaceae. The complete list of the species can be made available from the authors upon request.

\section{Vegetation classification}

Nine clusters can be recognized from the SYNTAX output at dissimilarity level above 0.7 (Fig. 2). These clusters were designated as local plant community types and given names after one or two dominating and/or characteristic species, usually a tree and a shrub. A dominant species in this case is a species having a synoptic cover-abundance value (mean frequency $\times$ mean coverabundance, sensu (Van der Maarel et al., 1987)) of at least 7, and a characteristic species being a species with synoptic values of 4,5 or 6 in the type but absent in most of the other community types. Synoptic cover-abundance values for the most important species are shown in Table 1.

The description of the plant community types based on the dominant and characteristic species with their altitudinal distribution is as follows. The cluster numbers in the dendrogram (Fig. 2) correspond to numbers of the community types in the subsequent discussion.

\section{Arundinaria alpina type}

The Arundinaria alpina type is found at altitudes from 2450 to $2550 \mathrm{~m}$. The dominant species of this type is the highland bamboo Arundinaria alpina $\mathrm{K}$. Schum. There is no shrub layer in this type. Dicliptera laxata C. B. Clarke and Pilea bambuseti Engl. are dominant species in the field layer. The characteristic species of the field layer is Laportea alatipes Hook. f. Lianas are not present in this community type. Isolated trees of Syzygium guineense (Willd.) Dc. and Schefflera volkensii (Engl.) Harms are present scattered through the bamboo stand. 


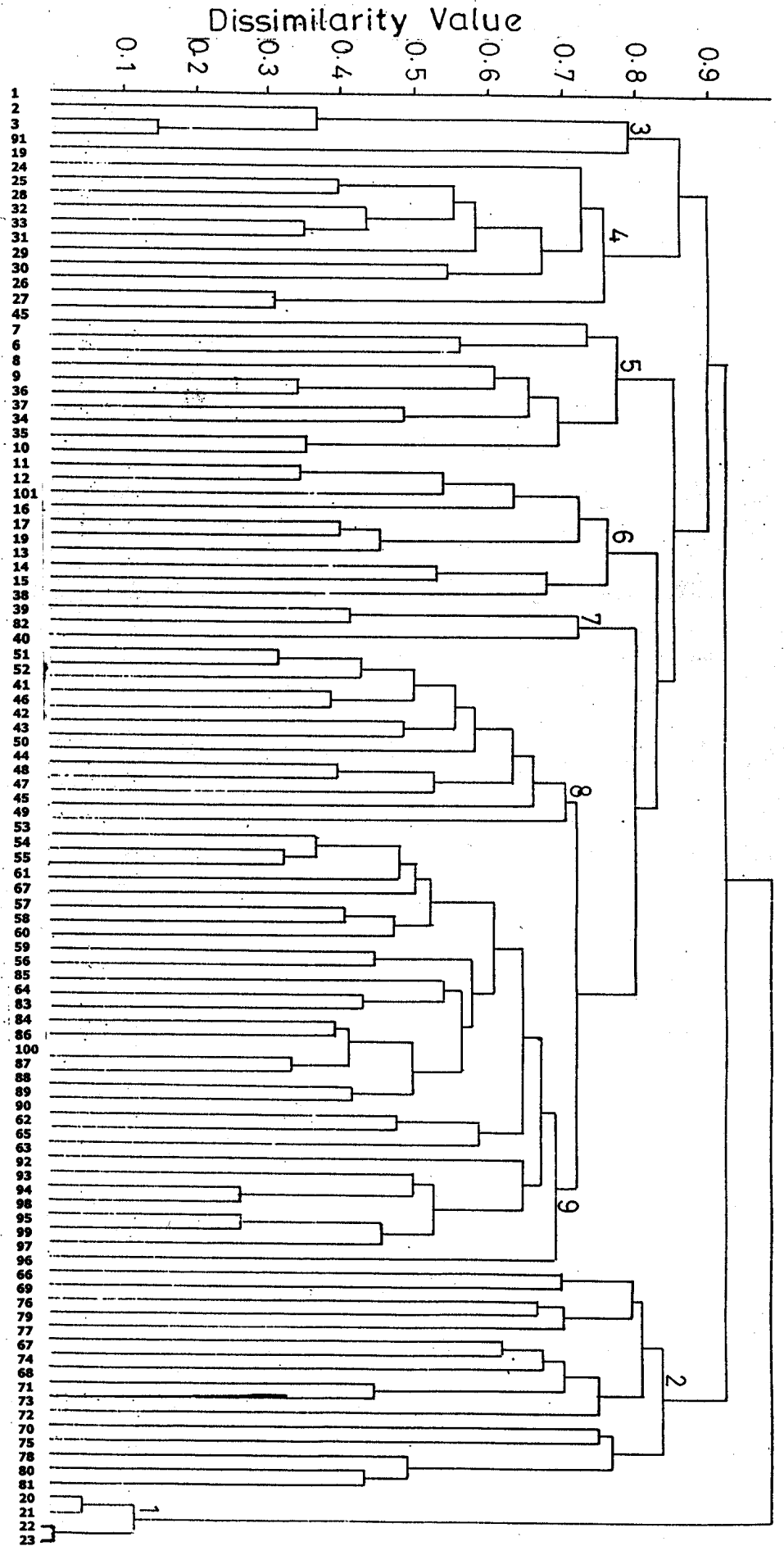

Fig. 2. Dendrogram of the relevè group of sothwestern Ethiopian forest. 
Table 1. Synoptic cover-abundance values for species reaching a value of $>1.5$ in at least one community type; values in bold refer to occurrences as characteristic species.

\begin{tabular}{|c|c|c|c|c|c|c|c|c|c|}
\hline \multirow[b]{2}{*}{ Species } & \multicolumn{9}{|c|}{ Cluster number } \\
\hline & 1 & 2. & 3 & 8 & 5 & 7 & 9 & 6 & 4 \\
\hline Arundinaria alpina & 9.0 & 0.0 & 0.0 & 0.0 & 0.0 & 0.0 & 0.0 & 0.0 & 0.0 \\
\hline Dicliptera laxata & 7.0 & 0.0 & 0.0 & 0.0 & 0.0 & 0.0 & 0.0 & 0.0 & 0.0 \\
\hline Pilea bambuseti & 7.0 & 0.0 & 0.0 & 0.0 & 0.0 & 0.0 & 0.0 & 0.0 & 0.0 \\
\hline Laportea alatipes & $\mathbf{5 . 0}$ & 0.0 & 0.0 & 0.0 & 0.0 & 0.0 & 0.0 & 0.0 & 0.0 \\
\hline Pteris dentata & 3.5 & .0 .0 & 1.3 & 0.0 & 0.0 & 0.0 & 0.0 & 4.9 & 4.4 \\
\hline Coffea arabica & 0.0 & 7.3 & 0.0 & 0.0 & 3.8 & 0.0 & 3.7 & 0.5 & 0.0 \\
\hline Manilikara butugi & 0.0 & 6.6 & 0.0 & 0.0 & 0.0 & 0.0 & 0.0 & 0.0 & 0.0 \\
\hline Argomuellera macrophylla & 0.0 & 3.1 & 0.0 & 0.0 & 0.0 & 0.0 & 0.0 & 0.0 & 0.0 \\
\hline Alchornea laxiflora & 0.0 & 2.1 & 0.0 & 0.0 & 0.0 & 0.0 & 0.0 & 0.0 & 0.0 \\
\hline Aningeria altissima & 0.0 & 1.6 & 0.0 & 0.0 & 0.0 & 0.0 & 0.0 & 0.0 & 0.0 \\
\hline Dracaena fragrans & 0.0 & 1.8 & 0.0 & 0.0 & 0.0 & 0.0 & 0.0 & 0.0 & 0.0 \\
\hline Brillantaisia madagascariensis & 0.0 & 2.6 & 0.0 & 0.0 & 0.0 & 0.0 & 0.0 & 0.0 & 0.0 \\
\hline Leptaspsis zeylanica & 0.0 & 2.8 & 0.0. & 0.0 & 0.0 & 0.0 & 0.0 & 0.0 & 0.0 \\
\hline Bersama abyssinica & 0.0 & 0.8 & 3.5 & 2.2 & 1.1 & 2.7 & 0.4 & 1.3 & 0.3 \\
\hline Canthium oligocarpum & 0.0 & 0.0 & 1.8 & 0.2 & 0.4 & 0.0 & 0.0 & 0.0 & 0.8 \\
\hline Maytenus gracilipes & 0.0 & 0.0 & $\dot{6} .3$ & 0.8 & 1.7 & 0.0 & 0.0 & 2.1 & 0.0 \\
\hline Vangueria apiculata & 0.0 & 0.0 & 3.2 & 0.0 & 0.4 & 0.0 & 0.0 & 0.0 & 0.0 \\
\hline Phaulopsis imbricata & 0.0 & 0.0 & 2.3 & 0.9 & 0.0 & 0.0 & 0.0 & 0.0 & 0.0 \\
\hline Impatiens hochstetteri & 0.0 & 0.0 & 7.3 & 0.0 & 0.0 & 0.0 & 0.0 & 0.0 & 3.1 \\
\hline Syzygium guineense & 0.0 & 0.0 & 7.5 & 7.1 & 1.8 & 2.0 & 3.1 & 1.8 & 2.5 \\
\hline Apodytes dimidiata & 0.0 & 0.0 & 5.8 & 4.8 & 0.0 & 0.0 & 0.0 & 0.5 & 0.0 \\
\hline Oplismenus compositus & 0.0 & 1.1 & 0.0 & 7.5 & 4.1 & 0.0 & 5.9 & 0.0 & 0.0 \\
\hline Acanthus eminens & 0.0 & 0.0 & 0.0 & 1.7 & 0.0 & 0.0 & 0.0 & 0.0 & 0.4 \\
\hline Maytenus obscura & 0.0 & 0.0 & 0.0 & 1.7 & 0.0 & 0.0 & 0.9 & 0.0 & 0.0 \\
\hline Piper capense & 0.0 & 0.1 & 0.0 & 1.9 & 0.0 & 0.0 & 0.0 & 1.5 & 0.5 \\
\hline Thelypteris longicuspis & 0.0 & 2.1 & 0.0 & 3.4 & 0.0 & 0.0 & 0.0 & 0.0 & 0.0 \\
\hline Dracaena afromontana & 0.0 & 0.8 & 0.5 & 5.9 & 7.1 & 3.7 & 1.8 & 4.2 & 4.5 \\
\hline Teclea nobilis & 0.0 & 0.0 & 0.0 & 2.2 & 4.8 & 1.0 & 2.8 & 4.1 & 0.3 \\
\hline Albizia grandibracteata & 0.0 & 0.0 & 0.2 & 0.9 & 2.8 & 0.0 & 0.0 & 0.0 & 1.6 \\
\hline Celtis africana & 0.0 & 1.3 & 0.0 & 0.0 & 5.1 & 0.0 & 0.0 & 0.0 & 0.0 \\
\hline Cordia africana & 0.0 & 1.3 & 0.0 & 0.0 & 2.3 & 0.0 & 0.0 & 0.0 & 0.0 \\
\hline Rothmannia urcelliformis & 0.0 & 2.3 & 0.0 & 0.7 & 3.6 & 1.7 & 0.0 & 2.2 & 0.0 \\
\hline Pseudechinolaena polystachya & 0.0 & 0.0 & 1.3 & 1.8 & 5.1 & 8.0 & 2.2 & 0.0 & 0.0 \\
\hline Chionanthes mildbraedii & 0.0 & 0.0 & 0.0 & 3.5 & 3.5 & 6.0 & 4.1 & 3.6 & 0.1 \\
\hline Rytigynia neglecta & 0.0 & 0.0 & 1.5 & 1.4 & 0.9 & 2.3 & 1.6 & 1.1 & 1.1 \\
\hline Aningeria adolfi-friederici & 0.0 & 0.0 & 0.0 & 1.6 & 0.9 & 7.0 & 0.0 & 4.2 & 0.0 \\
\hline Poecilostachyus oplismenoides & 0.0 & 2.1 & 1.1 & 1.5 & 0.0 & 8.0 & 1.7 & 3.4 & 0.0 \\
\hline Croton macrostachyus & 0.0 & 0.4 & 1.5 & 2.3 & 1.2 & 6.0 & 0.0 & 1.8 & 0.6 \\
\hline Diospyros abyssinica & 0.0 & 1.0 & 0.0 & 0.0 & 2.8 & 4.0 & 0.0 & 1.7 & 0.5 \\
\hline Psychotria orophila & 0.0 & 0.0 & 0.0 & 3.0 & 0.8 & 4.0 & 0.9 & 0.0 & 2.8 \\
\hline Desmodium repandum & 0.0 & 0.6 & 0.0 & 5.5 & 0.0 & 6.0 & مी & 0.0 & 0.0 \\
\hline Olea welwitschii & 0.0 & 0.0 & 0.0 & 2.0 & 2.5 & 0.0 & 5.4 & 1.5 & 0.0 \\
\hline Sapium elipticum & 0.0 & 1.2 & 0.0 & 0.0 & 1.2 & 0.0 & 2.2 & 2.7 & 0.0 \\
\hline Aframomum korarima & 0.0 & 0.0 & 0.0 & 0.0 & 0.0 & 0.0 & 4.1 & 2.2 & 0.0 \\
\hline Vepris daniellii & 0.0 & 0.6 & 0.0 & 0.0 & 0.0 & 0.0 & 2.8 & 0.0 & 0.3 \\
\hline Sanicula elata & 0.0 & 1.4 & 0.0 & 2.4 & 0.0 & 0.0 & 4.0 & 0.0 & 0.0 \\
\hline Polyscias fulva & 0.0 & 0.4 & 0.0 & 0.4 & 0.0 & 0.0 & 3.0 & 0.0 & 0.0 \\
\hline Achyranthus aspera & 0.0 & 1.0 & 0.0 & 0.0 & 0.0 & 0.0 & 1.4 & 0.0 & 0.0 \\
\hline Ficus sur & 0.0 & 0.1 & 0.0 & 1.1 & 0.2 & 1.3 & 0.8 & 2.7 & 0.0 \\
\hline Justicia schimperiana & 0.0 & 0.0 & 0.0 & 0.0 & 0.0 & 0.0 & 0.0 & 5.0 & 0.0 \\
\hline Albizia gummifera & 0.0 & 0.4 & 0.0 & 0.8 & 0.1 & 0.0 & 0.0 & 2.9 & 0.1 \\
\hline Millettia ferruginea & 0.0 & 1.1 & 0.3 & 0.0 & 2.3 & 0.0 & 2.7 & 2.8 & 0.5 \\
\hline Schefflera abyssinica & 0.0 & 0.0 & 0.0 & 2.1 & 0.0 & 0.0 & 2.5 & 2.7 & 0.4 \\
\hline Deinbollia kilimandscharica & 0.0 & 0.0 & 0.0 & 0.0 & 0.0 & 0.0 & 0.0 & 1.9 & 1.2 \\
\hline Allophylus abyssinicus & 0.0 & 0.0 & 1.3 & 0.0 & 0.0 & 0.0 & 0.9 & 5.2 & 2.6 \\
\hline Schefflera abyssinica & 0.0 & 0.0 & 0.0 & 2.1 & 0.0 & 0.0 & 2.5 & 2.7 & 0.4 \\
\hline Cyathea manniana & 0.0 & 0.0 & 0.0 & 0.6 & 0.0 & 0.0 & 0.0 & 0.0 & 4.1 \\
\hline Galiniera saxifraga & 0.0 & 0.0 & 0.0 & 0.7 & 0.5 & 0.0 & 0.5 & 2.0 & 5.3 \\
\hline Ilex mitis & 0.0 & 0.0 & 0.0 & 0.0 & 0.0 & 0.0 & 0.0 & 2.9 & 5.1 \\
\hline Macaranga capensis & 0.0 & 0.9 & 1.3 & 0.0 & 0.0 & 0.0 & 0.0 & 0.0 & 3.5 \\
\hline Maytenus arbutifolia & 0.0 & 0.0 & 0.0 & 0.0 & 0.0 & 2.3 & 0.0 & 0.0 & 2.5 \\
\hline Aneilema beninese & 0.0 & 0.6 & 0.0 & 0.0 & 0.0 & 0.0 & 0.0 & 0.0 & 2.9 \\
\hline Elatostemma monticolum & 0.0 & 0.0 & 0.0 & 2.2 & 0.0 & 0.0 & 0.0 & 0.0 & 2.5 \\
\hline Asplenium bogoiense & 0.0 & 0.0 & 0.0 & 0.0 & 0.0 & 0.0 & 0.0 & 0.0 & 4.3 \\
\hline
\end{tabular}


2. Manilkara butugi-Coffea arabica type

This community type is distributed at altitudes between 1050 and $1500 \mathrm{~m}$. Manilkara butugi Chiov. is the characteristic species in the tree layer and Coffea arabica L. is the dominant species in the shrub layer. Pouteria altissima (A. Chev) Baehni, Alchornea laxiflora (Benth.) Pax \& Hoffm., Argomuellera macrophylla Pax, Celtis zenkeri Engl., and Dracaena fragrans (L.) Ker-Gawler are trees and shrubs associated with this type. Brillantaisia madagascariensis And. ex Lindau., Leptaspsis zeylanica Nees ex Steud., and Dorstenia sorensenii Friis are species in the field layer and recorded in this type alone. Other associated species in this type include Strychnos mitis S. Moore, Garcinia buchananii Bak., Hallea robrostipulata (K. Schum.) J. F. Leroy, Morus mesozygia Stapf, and Rungia grandis T. Landolphia buchananii (Hall. F.) Stapf, Combretum paniculatum and Hippocratea africana (Willd.) Loes. are lianas abundant in this type.

3. Syzygium guineense-Maytenus gracilipes type

This community type is distributed at altitudes between 2280 and $2420 \mathrm{~m}$. Syzygium guineense and Apodytes dimidiata are the dominant species in the tree layer. Maytenus gracilipes (Welw. Ex Oliv.) Exell and Vangueria apiculata K. Schum. are the characteristic species in the shrub layer. Impatiens hochstetteri Warb. is the dominant species in the field layer. The lianas Landolphia buchananii and Urera hypeselodendron (A. Rich) Wedd. are well represented in this type.

4. Ilex mitis-Galiniera saxifraga type

The altitudinal distribution of this community type extends from 1950 to 2340 $\mathrm{m}$. a.s.l. The characteristic species of this type are Ilex mitis (L.) Radlk., Galiniera saxifraga (Hochst.) Bridson, and the tree fern, Cyathea manniana Hook.. Asplenium bugoiense Hieron. and Pteris dentata Forssk. are the characteristic species in the field layer. Drymaria cordata (L.) Roem. \& Schultes and Triestemma mauritanum J. F. Gmelin were herbs recorded from this type only. Hippocratea africana and Landolphia buchananii are the lianas represented in this type.

5. Celtis africana-Dracaena afromontana type

This type is distributed at altitudes between 1460 and $1960 \mathrm{~m}$. Celtis africana Burm. f. is the characteristic species of the tree layer, while Dracaena afromontana Mildbr. is the dominant species in the shrub layer. The grass Pseudechinolaena polystachya (Kunth) Stapf is the characteristic species in the field layer. Ritchia albersii Gilg. was recorded from this community type only. The lianas most abundant in this type are Landolphia buchananii, Combretum paniculatum Vent., Hippocratea goetzei, and H. africana.

\section{Allophylus abyssinicus-Justicia schimperiana type}

This community type is distributed at altitudes between 1760 and $2030 \mathrm{~m}$. Allophylus abyssinicus (Hochst.) Radlk. and Pouteria adolfi-friederici are the characteristic species in the tree layer. Justicia schimperiana is the characteristic 
shrub. The dominant species of the field layer is Pteris dentata. Lianas and woody climbers represented in this type are Hippocratea goetzei, $H$. africana, Tiliacora troupinii Cuffod., Combretum paniculatum, and Jasminum abyssinicum Hochst. ex DC.

7. Pouteria adolfi-friederici-Chionanthes mildbraedii type

This community type is distributed at altitudes between 1880 and $1940 \mathrm{~m}$. Pouteria adolfi-friederici (Engl.) Baehni is the dominant species of the tree layer. Croton macrostachyus Del. and Diospyros abyssinica (Hiern) F. White are the characteristic species in the tree layer. Chionanthes mildbraedii (Gilg \& Schellenb.) Stearn is the characteristic species in the shrub layer. Pseudechinolaena polystachya and Poecilostachyus oplismenoides (Hack.) W. D. Clayton are dominant in the field layer and Desmodium repandum (Vahl) Dc. is the characteristic species in the same layer. Landolphia buchananii and Hippocratea goetzei are the lianas most abundant here.

8. Syzygium guineense-Thelypteris longicuspis type

This type is distributed at altitudes from 1845 to $2240 \mathrm{~m}$. The dominant species in the tree layer is Syzygium guineense. Apodytes dimidiata is the characteristic species. Oplismenus compositus is the dominant grass in the field layer and Desmodium repandum is the characteristic herb. Landolphia buchananii and Combretum paniculatum are the lianas abundant in this type.

9. Olea welwitschii-Aframomum corrorima type

This community type is distributed between 1675 and $2010 \mathrm{~m}$. a.s.l. This community type is characterized by Olea welwitchii (Knobl.) Gilg. \& Schellenb. in the tree layer. Schefflera abyssinica (Hochst. ex A. Rich.) Harms, Polyscias fulva (Hiern) Harms and Vepris daniellii (Pichi-Sermolli) Kokwaro are the associated trees. Chionanthes mildbraedii is the characteristic shrub. Oplismenus compositus (L.) P. Beauv., Sanicula elata Ham. Ex Don, and Aframomum corrarima (Per.) Engler are characteristic herbs in the field layer. Landolphia buchananii, Hippocratea africana, $H$. goetzei, and Combretum paniculatum are common lianas prersent in this type.

\section{Community-environment relationship}

The community types identified from the classification output showed significant differences with respect to all the environmental parameters in the topsoil. However, significant differences were observed in slope, aspect, exchangeable sodium, and exchangeable potassium, cation exchange capacity, and available phosphorus in the subsoil. The values of the various environmental parameters averaged for each plant community type are presented in Table 2. 


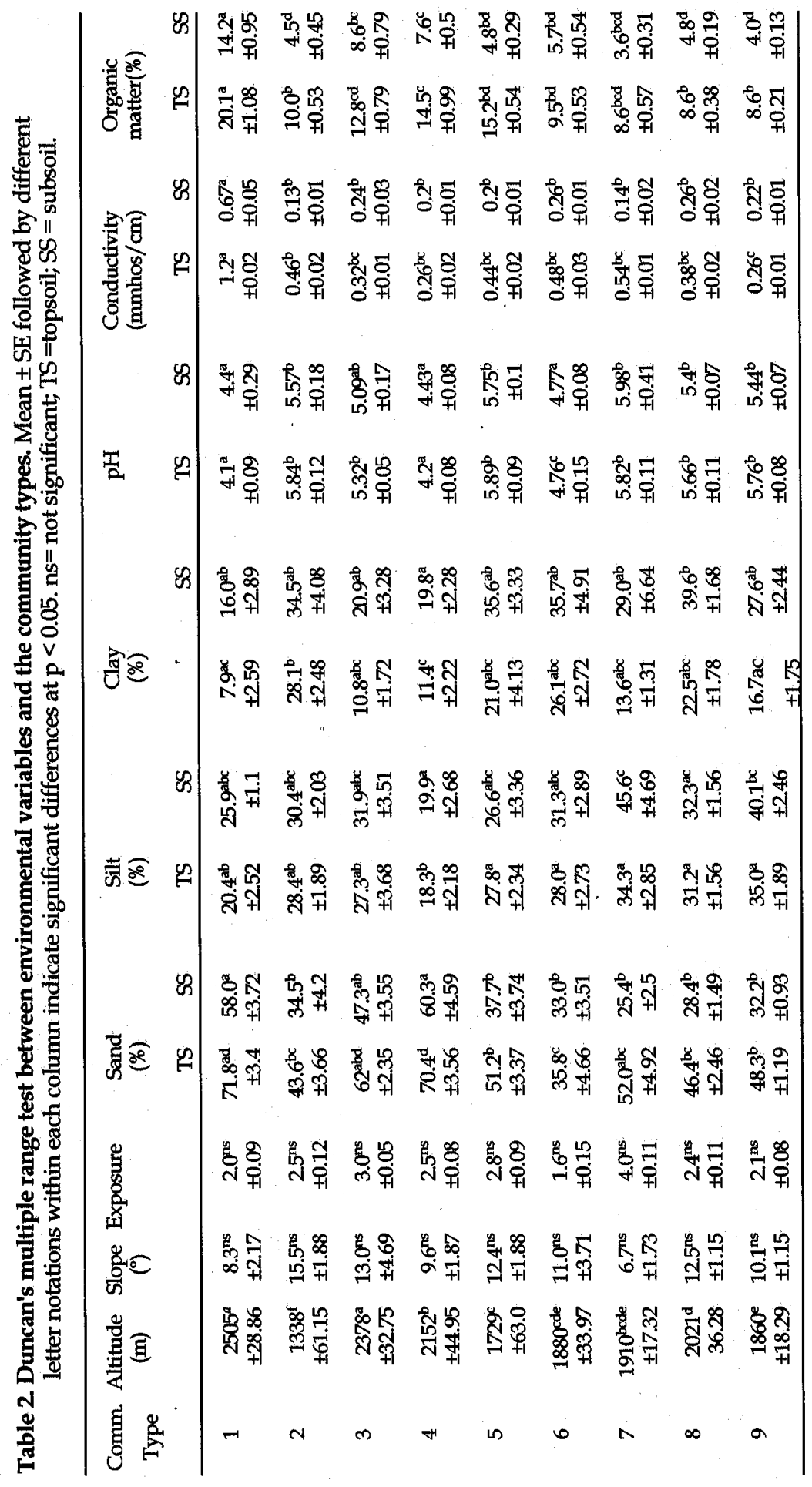




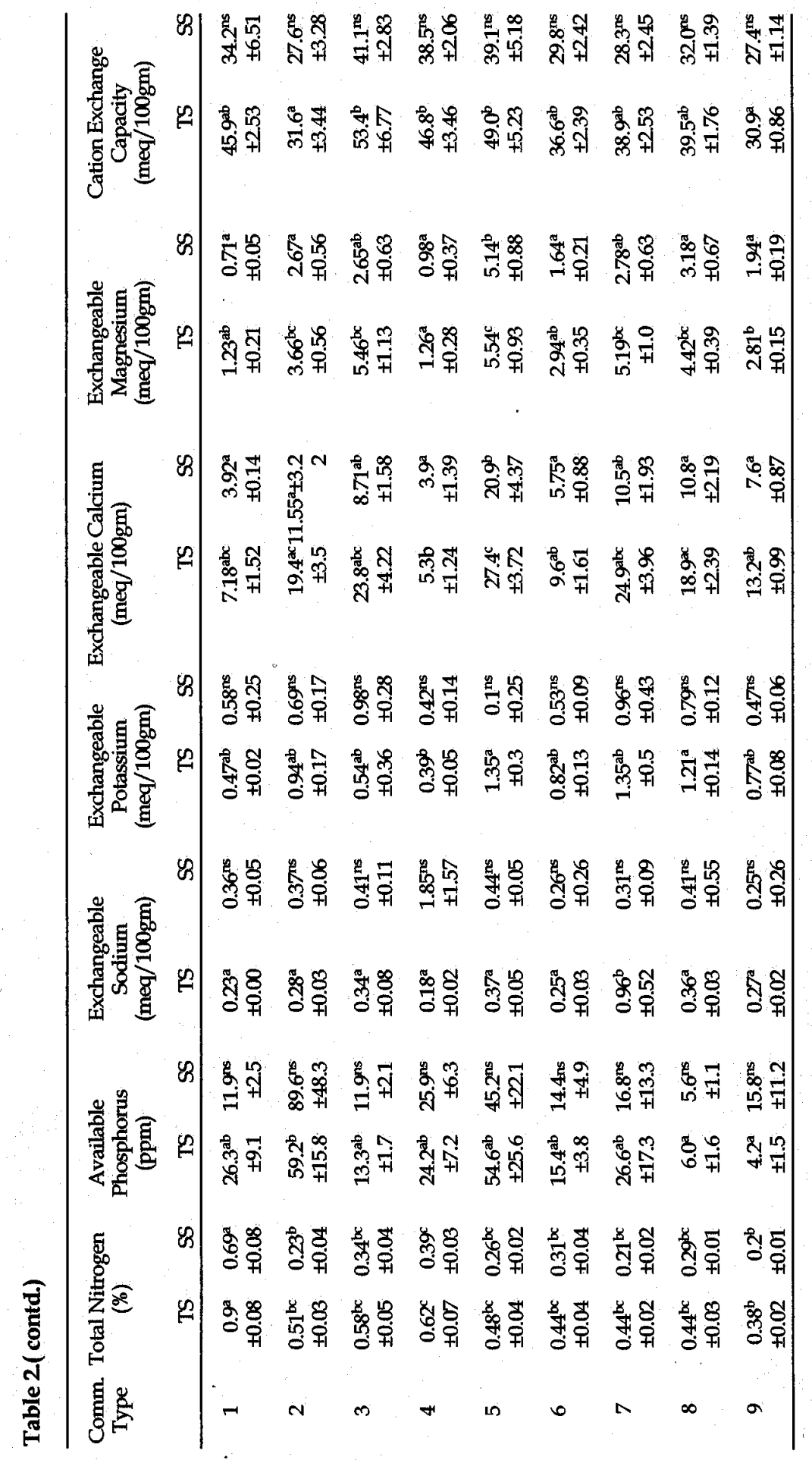


The major discrimination among the community types is due to altitude. Bonnefille et al. (1993) reported from palynological studies of forests and woodlands the presence of altitudinal zonation delimiting vegetation types in southwestern Ethiopia. Altitude is an important environmental factor that affects atmospheric pressure, moisture, and temperature which have a strong influence on the growth and development of plants and the distribution of vegetation (Hedberg, 1964).

The topsoils were categorized into 5 textural classes and the subsoils into 3: loamy sand (communities 1 and 4), clay loam (community 2), sandy loam (community 3), sandy clay loam (community 5), and loam (communities 6, 7, 8 , and 9). The subsoil texture class includes sandy loam (communities 1 and 4), loam (community 3), and clay loam (communities 2, 5, 6, 7, 8, and 9). Soil texture is an important soil parameter that affects site quality. It influences the nutrient supplying ability of soil solids, soil moisture and air relations, and root development (Spurr and Barnes, 1980).

Comparison of the community types based on the sand content of the soil shows that type 1 is significantly different from types 2, 5, 6, 8, and 9, and type 4 differs from types $2,5,6,7,8$, and 9 in both the topsoil and subsoil, and type 6 differs from types 3,5, and 9 for topsoil. Community type 4 differs from types 8 and 9 in its silt content in the topsoil and from types 7 and 9 in the subsoil. Community types 8 and 9 differ in their silt content in the subsoil. Community type 2 differs from types 1 and 9 and community type 4 from type 2 and 6 in the clay content of topsoil and community types 4 and 8 differ in the clay content of subsoil.

The soils of southwestern Ethiopia are acidic with $\mathrm{pH}$ value ranges between 4 and 6. Acidic soils of medium intensity (i.e., $\mathrm{pH} 4$ and 5) were recorded for community types 1, 4, and 6 while slightly acidic soils (i.e., pH 5 and 6) were recorded for the rest. The acidity of the soil could be caused by a more intense breakdown of organic matter and leaching of the soil attributable to the very high annual rainfall. Soil $\mathrm{pH}$ affects the growth of plants and the distribution of vegetation types by its effect on the availability of mineral nutrients and decomposition of organic matter (Buckman and Brady, 1969).

Community type 1 is different from the remaining types in soluble salts in both the topsoil and subsoil, and type 2 differs from type 9 in topsoil. The electrical conductivity of the soil solution is mainly determined by soluble salts of carbonates, bicarbonates, sulphates, chlorides and nitrates (Chopra and Kanwar, 1982). The concentration of salts in the soil solution influences an exchange of nutrients between the soil solution and plants.

The organic matter content of the soils is generally high (8.6-20.1\%). There is significant variation in the organic matter content of the soils of the plant community types. Community type 1 is different from the other types and 
type 4 differs from types $2,5,6,8$, and 9 . Community type 3 differs from types 2,8 and 9. Community types 1 and 4 are from a region which receives higher amounts of annual rainfall with lower temperature. The higher amount of organic matter is due to the inhibition of mineralization of organic matter by low temperature and acidic $\mathrm{pH}$. The high organic matter content is important due to its impact on the fertility status and productivity of the soils. The mineralization of organic matter contributes to the supply of available mineral nutrients for plant use (Murphy, 1969). Higher amount of organic matter content has also been reported from the humid forest of Jibat (Tamrat Bekele, 1994). Westphal (1975) indicated that dark red-brown soils that are slightly to strongly acid have higher organic matter content.

The total nitrogen content of the soil follows closely the amount of organic matter. It is higher in those community types with higher organic matter content and lower in those having lower organic matter content. Much of the soil nitrogen is in the organic form and its distribution in the soil is approximately as that of the organic matter (Thompson and Troeh, 1979).

Community types 2,4 , and 5 have higher amount of available phosphorus, types 3, 6 and 9 have medium amount and type 8 has lower amount of available phosphorus both in topsoil and subsoil while community types 1 and 7 have higher amount in topsoil and medium amount in subsoil. There is no much difference between the community types in available phosphorus except the differences between community type 2 and types 8 and 9 .

The soils of the community types are rich in exchangeable bases particularly in exchangeable calcium, which accounts for $70.5-79.9 \%$ and $54.5-76 \%$ of the exchangeable bases in the topsoil and subsoil, respectively. There is no variation among the community types in exchangeable sodium except for type 7, which differs from the other types for topsoil only. Community type 4 differs from types 5 and 8 in its exchangeable potassium and from types 2, 5, and 8 in exchangeable calcium of the topsoil. In the subsoil, type 5 differs from types $1,2,4,6,8$, and 9 in exchangeable calcium. The variation could be accounted to the differences in soil $\mathrm{pH}$ and the amount of rainfall. The amount of exchangeable calcium and potassium present in the soil decline as a soil becomes more acidic and increases as the acidity declines (Thompson and Troeh, 1979). Community type 5 significantly differs in exchangeable magnesium from community types $1,4,6$, and 9 in the topsoil and community types 1, 2, 4, 6, 8, and 9 in the subsoil and community type 4 differs from community types $2,3,5,7,8$, and 9 in the topsoil.

The exchangeable bases have their highest concentration in community types 3,5 , and 7 and these communities occurred in areas that received the least amount of rainfall resulting in little loss of the cations by leaching. 
The cation exchange capacity (CEC) of the soils is generally low. The CEC of the soils of community types 3, 4, and 5 is higher than the soils of types 2 and 9 . The factors that influence CEC are texture, organic matter, and $\mathrm{pH}$ of the soil (Thompson and Troeh, 1979), but these contrasting groups of community types showed different degree of variability in terms of these factors, therefore, no single factor is responsible for the observed variation. The base saturation of the soils increases from $19.8 \%$ to $83.3 \%$ as $\mathrm{pH}$ rises from 4.1 to 5.8. Those community types whose soils' $\mathrm{pH}$ are relatively higher have most of their cation exchange portion occupied by basic cations $\left(\mathrm{K}^{+}, \mathrm{Na}^{+}, \mathrm{Ca}^{++}\right.$, and $\mathrm{Mg}^{++}$) and those whose $\mathrm{pH}$ is lower have most of their cation exchange portion occupied by acidic cations $\left(\mathrm{H}^{+}\right.$and $\left.\mathrm{Al}^{+++}\right)$(Thompson and Troeh, 1979).

The results of Pearson's product-moment correlation of the environmental parameters (Table $3 a$ and $3 b$ ) show that some of the environmental parameters are correlated. Altitude is positively correlated with sand and organic matter in topsoil and with electrical conductivity, organic matter and total nitrogen in subsoil, but negatively with clay in both topsoil and subsoil and available phosphorus in subsoil. Organic matter, total nitrogen and electrical conductivity are positively correlated in both topsoil and subsoil.

With increasing altitude, rainfall amount increases and this results in the loss of the silt fraction first, the clay fraction next and the sand fraction is the last to be washed away. The correlation of organic matter with electrical conductivity could be explained by its capacity to supply replaceable cations to the soil solution that increases the conductivity. The sand content of the soil is positively correlated with organic matter and total nitrogen but negatively with silt and clay content of the soil in both the topsoil and subsoil.

The correlation of organic matter and nitrogen with sand contradicts the fact that sandy soils usually carry less organic matter and nitrogen (Buckmann and Brady, 1969). $\mathrm{pH}$ is positively correlated with silt, exchangeable calcium, magnesium, and potassium (topsoil) and negatively with sand (subsoil), organic matter and total nitrogen. When the soil $\mathrm{pH}$ is lower the rate of organic matter decomposition decreases. This is due to the effect of soil $\mathrm{pH}$ on the activity of soil microrganisms that are involved in the decomposition of organic matter. The positive correlation between $\mathrm{pH}$ and calcium, magnesium, and potassium is to be expected as soils that are highly leached have lower $\mathrm{pH}$ because the basic cations have lower proportions than the acidic cations (Buckman and Brady, 1969). Among the exchangeable bases, potassium, calcium, and magnesium are positively correlated. 


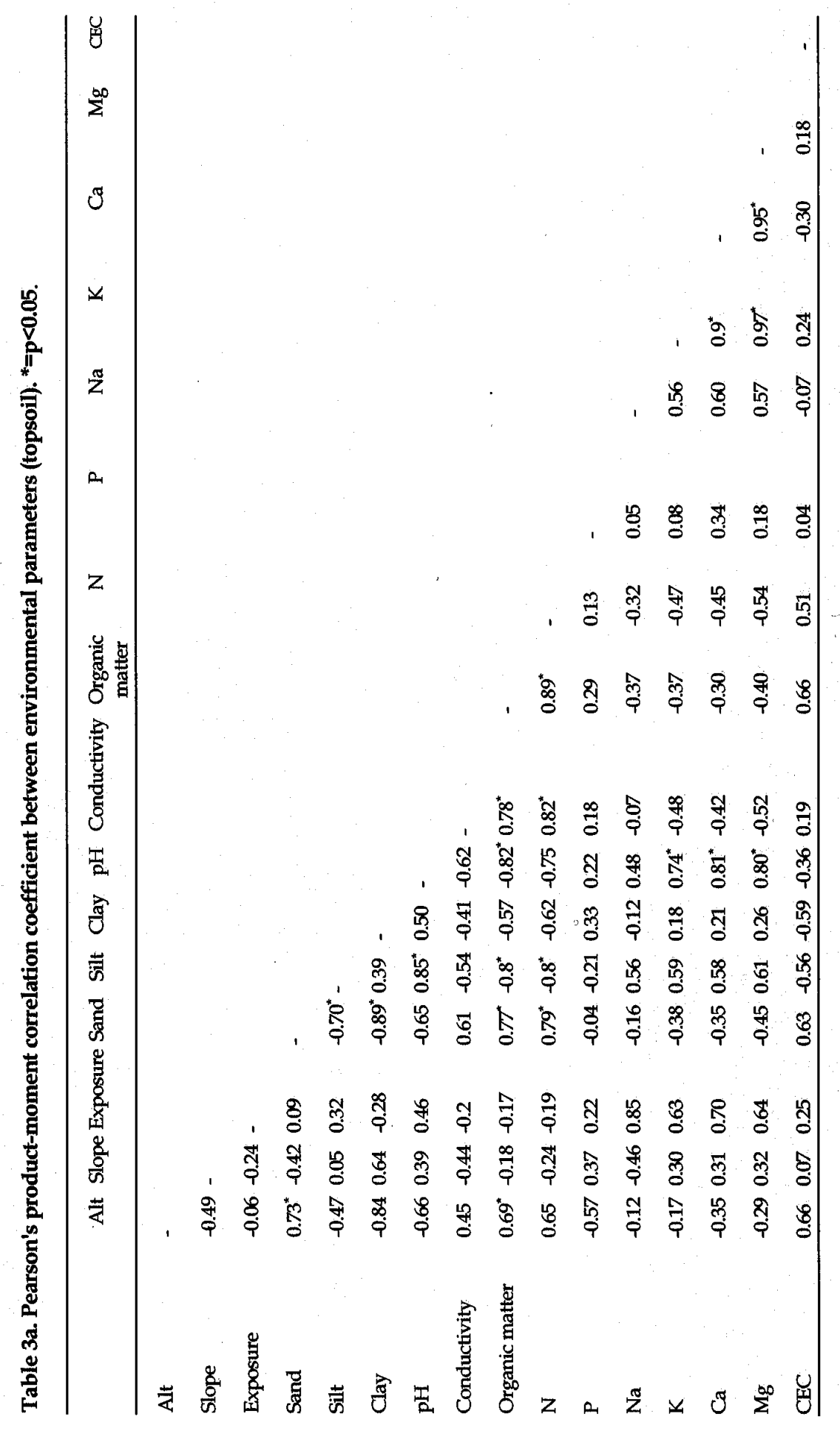




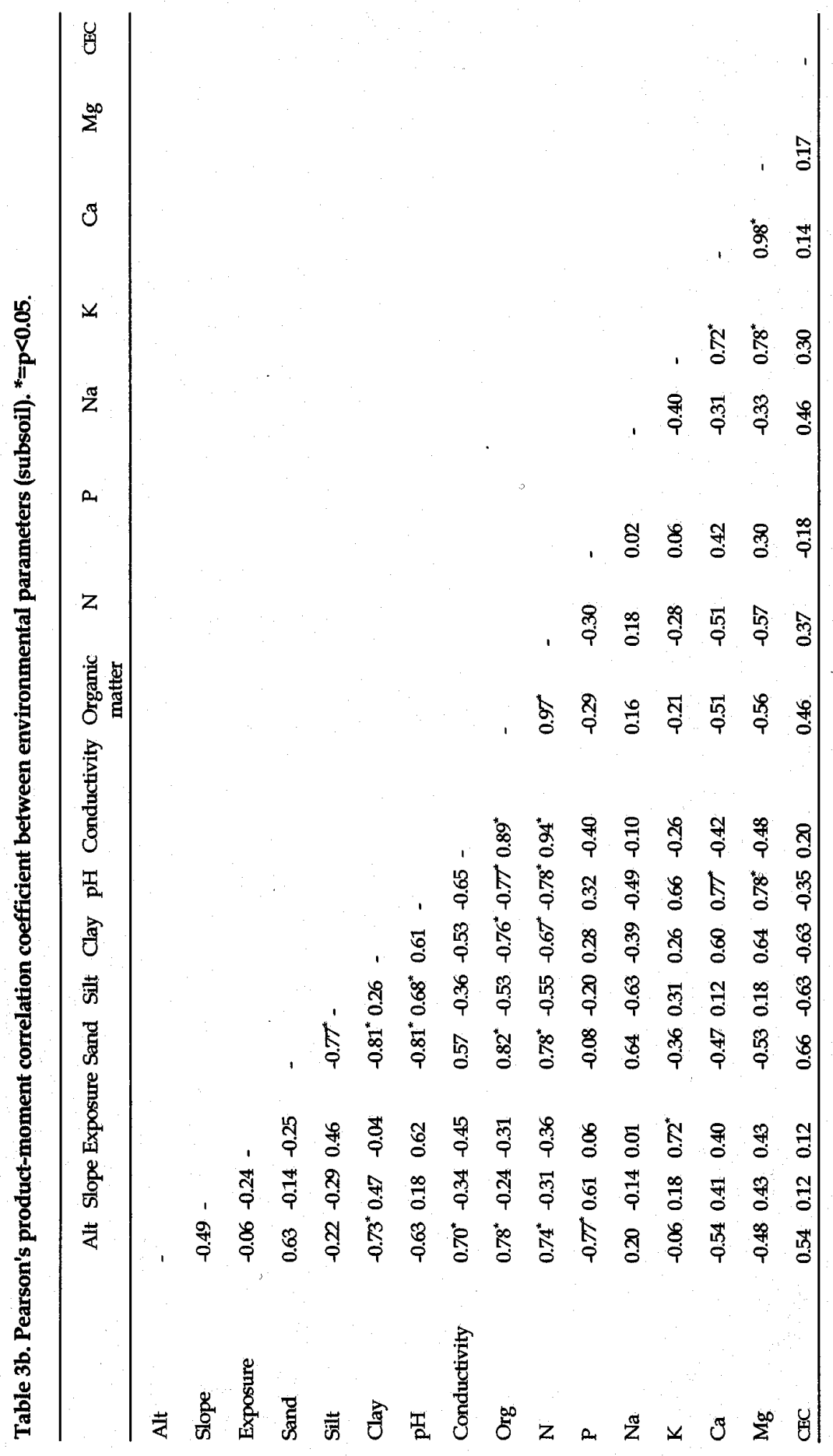




\section{Phytogeographical comparison}

The forests of southwestern Ethiopia are compared with other montane forests in Eastern and Southern Africa: two in Ethiopia, two in other East African countries and one in Southern Africa. The forests included in the comparison are Jibat forest and Harena forest in Ethiopia, Mt. Kenya forest in Kenya, Mt. Mulanje forest in Malawi and Mt. Elgon forest in Kenya/Uganda.

Jibat forest is located in western Shewa in western Ethiopia and lies at altitudes between 2000 and $3000 \mathrm{~m}$ (Tamrat Bekele, 1994). Harena forest is situated in the Bale Mountains National Park in southeastern Ethiopia with altitudinal distribution between 1510 and 3300 m (Lissanework Nigatu, 1987, Zerihun Woldu et al., 1989). Mt. Mulanje, the highest massif in Malawi, is situated in the south-east part of Malawi. The 'mid-altitude' and 'Afromontane forests' sensu Dowsett-Lemaire (1988) of Mt. Mulanje are distributed between 900 and $1950 \mathrm{~m}$ a.s.l. Mt. Elgon is a large volcano of Mioecene age straddling the Kenya/Uganda border. A belt of forest girdles the mountain between 2000 and $3000 \mathrm{~m}$ a.s.l. (Hamilton and Perott, 1981). Mt. Kenya is an isolated mountain of volcanic origin in Kenya. Forests cover the bulk of the mountain area, extending to approximately $3400 \mathrm{~m}$ altitude in the south and $3000 \mathrm{~m}$ in the north (Bussmann and Beck, 1995).

The comparison is based on the similarities in species distribution. A similarity analysis was carried out based on the presence of tree and shrub species in order to evaluate the relationship between these forests. The similarity index used is Sörensen's similarity coefficient $2 c /(a+b)$, where $c$ is the number of species shared by the forests compared, $a$ is the number of species in one forest, and $b$ is the number of species in the other forest. The results of the analysis are presented in Table 4.

Table 4. Floristic similarities between the forests in southwestern Ethiopia and five forests in Ethiopia, Kenya, Kenya/ Uganda and Malawi. $\mathbf{N}=$ number of species included in comparison, $\mathrm{C}=$ number of species in common, $\mathrm{S}=$ Sörensen's coefficient of similarity.

\begin{tabular}{lccc}
\hline Forest & N & C & S \\
\hline Jibat & 54 & 39 & 0.54 \\
Harena & 87 & 51 & 0.58 \\
Mt. Mulanje & 137 & 30 & 0.26 \\
Mt. Elgon & 61 & 22 & 0.29 \\
Mt. Kenya & 160 & 39 & 0.3 \\
\hline
\end{tabular}

The forests in southwestern Ethiopia are floristically related more to the Harena and Jibat forests than to the forests on Mt. Kenya, Mt. Mulanje and Mt. Elgon. The Harena and Jibat forests are situated in the same climatic region as 
those of the forests in southwestern Ethiopia. The Harena forest in the moister side of the Southeastern Highland and the Jibat forest in the moister side of the Northwestern Highland. Therefore, the highest floristic similarity between these forests is due to similar distribution in the moister parts of the country. The forests of Mt. Kenya, Mt. Mulanje and Mt. Elgon are exposed to a moister climate but they are geographically far from the forests of southwestern Ethiopia.

Hedberg (1951) recognized three-vegetation belts in East African mountains: Montane belt; Ericaceous belt; and Afroalpine belt. The montane belt is divided into three zones: montane forest zone; bamboo zone; and HageniaHypericum zone. The Ericaceous and Afroalpine belts are not represented in southwestern Ethiopia, only the montane belt is represented. The montane forest and bamboo zones have been described in this study; the former from Jiren, Yayu, Gebre Dima, Sele-Anderacha, Bonga, and Belete-Gera forests and the latter from Sele-Anderacha forest. The Hagenia-Hypericum zone has not been encountered, this is because the altitudinal range covered in this study is below the lower limit of Hagenia-Hypericum zone.

Among the seven forest types described by Friis (1992), four are represented in southwestern Ethiopia: Afromontane rain forest; Transitional rain forest; Dry peripheral semi-deciduous Guineo-Congolian forest; and Riverine forest. Except Sheko forest, the remaining forests investigated in this study are Afromontane type with characteristic Afromontane flora.

Among the Afromontane taxa some are endemic, i.e., confined to the Afromontane region only, e.g. Pouteria adolfi-friederici, Dracaena afromontana, Millettia ferruginea (Hochst.) Bak, Olea welwitschii, and Arundinaria alpina. Some Afromontane endemic species are forest pioneers, e.g., Bersama abyssinica Fresen. Some others are linking species, i.e. occurring in the Afromontane region and in other phytochoria, e.g. Croton macrostchyus, Ficus thonningi Blume, and Phoenix reclinata Jacq.. Other species are transgressors, i.e., occurring in two or more major phytochoria and are characteristic members of two or more vegetation types, e.g., Cassipourea malosana (Bak.) Alston and Celtis africana.

The Transitional rain forest type is represented in Sheko forest and in the river valleys of Yayu forest. The species in these forests are either characteristic Afromontane, (e.g. Manilkara butugi, Olea hochstetterri Bak., and Macaranga capensis (Baill.) Sim) or Guineo-Congolioan, (e.g. Pouteria altissima and Argomuellera macrophylla) or Guineo-Congolian linking species, (e.g. Alchornea laxiflora, Celtis zenkeri, Dracaena fragrans, Ehretia cymosa Thonn., Morus mesozygia, Rothmannia urcelliformis (Hiern) Robyns, Sapium ellipticum (Hochst. ex Krauss.) Pax, and Trilepisium madagascariense DC. 


\section{ACKNOWLEDGEMENTS}

We would like to acknowledge the Swedish Agency for Research Co-operation with Developing Countries (SAREC) for the financial support and the staff of the National Soil Laboratory, Ministry of Agriculture, Ethiopia for allowing the first author to perform some of the soil analysis in their laboratory. We acknowledge the constructive comments given by an anonymous referee.

\section{REFERENCES}

1. Becking, R.W. (1957). The Zürich-Montpellier school method of phytosociology. Bot.Rev. 23:411-488.

2. Bonnefille, R., Buchet, G., Friis, I., Ensermu Kelbessa and Mohammed, M.U. (1993). Modern pollen rain on an altitudinal range of forests and woodlands in southwest Ethiopia. Opera Bot. 121: 71-84.

3. Buckman, H.O. and Brady, N.C. (1969). The Nature and Properties of Soils. $7^{\text {th }}$ ed. The Macmillan company, USA, 653 pp.

4. Bussmann, R.W. and Beck, E. (1995). The forests of Mt. Kenya (Kenya), aphytosociological synopsis. Phytocoenologia 25(4):467-560.

5. Chaffey, D.R. (1979). Southwest Ethiopia Forest Inventory Project. A reconnaissance inventory of forest in southwest Ethiopia. Project report 31.

6. Chopra, S.L. and Kanwar, J.S. (1982). Analytical Agricultural Chemistry. Kalyani Publishers, New Delhi.

7. Cuffodontis, G. (1953-1972). Enumeratio Plantarum Ethiopae. Bull. Jard. Bot. Etat Brux., Bruxelles, Vols. 23-42.

8. Daniel Gamachu (1977). Aspects of Climate and Water Budget in Ethiopia. Addis Ababa University Press, Addis Ababa, 71 pp.

9. Dewis, J. and Freitas, F. (1984). Physical and chemical methods of soil and water analysis. FAO Soil Bullettin No. 10.

10. Dowsett-Lemaire, F. (1988). The forest vegetation of Mt. Mulanje (Malawi): a floristic and chorological study along an altitudinal gradient (650-1950 m). Bull. Jard. Bot. Nat. Belg. 55:77-107.

11. Edwards, S., Mesfin Tadesse and Hedberg, I. (eds) (1995). Flora of Ethiopia and Eritrea, Vol. 2 part 2. Addis Ababa University, Addis Ababa, $456 \mathrm{pp}$.

12. EFAP (1994). The Challenge for Development. Ethiopian Forestry Action Program, Vol.II, Addis Ababa.

13. FAO/UNESCO (1974). Soil Map of the World, 1: 5,000,000. Vol.6.UNESCO, Paris.

14. Friis, I. (1992). Forests and Forest Trees of Northeast Tropical Africa. Kew Bulletin, Additional Series XV, 383 pp.

15. Friis, I., Rasmussen, F.N. and Vollesen, K. (1982). Studies in the flora and vegetation of southwest Ethiopia. Opera Bot. 63:8-70.

16. Hamilton, A.C. and Perrot, R.H. (1981). A study of altitudinal zonation in the montane forest belt of Mt. Elgon, Kenya/Uganda. Vegetatio 45:107-125.

17. Hedberg, O. (1951). Vegetation belts of the East African montains. Sven. Bot. Tidskr. 45:140-204. 
18. Hedbarg, O. (1964). Features of Afroalpine plant ecology. Acta phytogeoger. Suec. 49:1-144.

19. Hedberg, I. and Edwards, S. (eds) (1989). Flora of Ethiopia. Vol.3. Addis Ababa University, Addis Ababa, $659 \mathrm{pp}$.

20. Hedberg, I. and Edwards, S (eds) (1995). Flora of Ethiopia. Vol.7. Addis Ababa University, $420 \mathrm{pp}$.

21. Jou, A.S.R. (ed) (1978). Selected Methods for Soil and Plant Analysis. International Institute of Tropical Agriculture, Ibadan, Nigeria.

22. Lissanework Nigatu (1987). An ecological study of the vegetation of the Harrena forest. MSc Thesis, Addis Ababa University.

23. Logan, W.E.M. (1946). An Introduction to the forests of Central and Southern Ethiopia. Imperial Forest Institute, University of Oxford. Inst. Paper, No. 24, $58 \mathrm{pp}$.

24. Mohr, P.A. (1971). The Geology of Ethiopia, $2^{\text {nd }}$ ed. University College of Addis Abeba Press, Addis Abeba.

25. Mueller-Dombois, D. and Ellenberg, H. (1974). Aims and Methods of Vegetation Ecology. John Wiley \& Sons, New York, 531 pp.

26. Murphy, H.F. (1968). A Report on the Fertility Status and Other Data on Some Soils of Ethiopia. College of Agriculture, Haile Sellassie I University.

27. Podani, L. (1988). Syntax III. Uers's manual. Abstracta Botanica 12:1-183.

28. Poore, M.E.d. (1955). The use of phytosociological methods in ecological investigations. I. The Braun-Blanquet system . J. Ecol. 43:226-244; II. Practical issues involved in an attempt to apply the Braun-Blanquet System. J. Ecol. 43:245-269; III. Practical applications. J. Ecol. 43:606-656.

29. Poore, M.E.D. (1956). The use of phytosociological methods in ecological investigations. IV. General discussion of phytosociological problems. J. Ecol. 44:28-50.

30. Spurr, S.H. and Barnes, B.V. (1980). Forest Ecology $3^{\text {rd }}$ ed. John Wiley \& Sons, 679 pp.

31. Tamrat Bekele (1994). Phytosociology and ecology of a humid Afromontane forest in the central plateau of Shewa, Ethiopia. J. Veg. Sci. 5:87-98.

32. Thompson, L.M. and Troeh, F.R. (1979). Soils and Soil Fertility. McGraw-Hill, Inc., $519 \mathrm{pp}$.

33. Van der Maarel, E. (1979). Transformation of cover/abundance values in phytosociology and its effect on community similarity. Vegetatio 39:97114.

34. Van der Maarel, E., Espeje, H. and Moreno-Casasola, P. (1987). Two-step vegetation analysis based on very large data sets. Vegatatio 68:139-143.

35. Westhoff, V. and van der Maarel, E. (1978). The Braun-Blanquet approach. In: Classification of Plant Communities, pp. 287-399, (Whitaker, R.H., ed.). Junk, The Hague.

36. Westphal, E. (1975). Agricultural systems in Ethiopia. Agri. Res. Rep., Wageninngen, $278 \mathrm{pp}$.

37. Zerihun Woldu, Feoli, E., and Lissanework Nigatu (1989). Partitioning an elevation gradient of vegetation from Southeastern Ethiopia by probabilistic methods. Vegetatio 18:189-198. 